\title{
Effect of T-2 and HT-2 Toxin during the Growing Period on Body Weight, Lipid Peroxide and Glutathione Redox Status of Broiler Chickens
}

\author{
Mária Weber ${ }^{1}$, Krisztián Balogh ${ }^{2,3}$, Judit Fodor ${ }^{3}$, Márta Erdélyi², Zsolt Ancsin², \\ Miklós Mézes ${ }^{2}$ \\ ${ }^{1}$ Department of Pig and Small Animal Breeding, Institute of Animal Husbandry, ${ }^{2}$ Department of Nutrition, \\ Szent István University, Gödöllö, Hungary \\ ${ }^{3}$ Research Group of Animal Breeding and Hygiene, Faculty of Animal Science, University of \\ Kaposvár, Hungary \\ Received January 15, 2009 \\ Accepted June 30, 2009
}

\begin{abstract}
The effect of T-2 and HT-2 toxin using different doses in the starter (0-21 days: $1.04 \mathrm{mg}$ T-2 toxin and $0.49 \mathrm{mg} \mathrm{HT}-2$ toxin $\mathrm{kg}^{-1}$ feed), and finisher diets (22-39 days: $0.12 \mathrm{mg}$ T-2 toxin and $0.02 \mathrm{mg}$ HT-2 toxin $\cdot \mathrm{kg}^{-1}$ feed) was investigated in broiler chickens. Birds were divided into two groups fed with control and T-2 and HT-2 toxin contaminated diets. Pathological signs of toxicity were investigated on days 21 and 39 of the trial, individual liveweight was measured weekly. Five birds from each group were sacrificed on the $21^{\text {st }}$ and $39^{\text {th }}$ days of treatment, when blood plasma, red blood cell, liver and kidney samples were taken, in which malondialdehyde and reduced glutathione concentration and glutathione-peroxidase activity were determined.

Pathological signs (lesions in the oral cavity and on the tongue, inflammation in the small intestine) were found in the group fed T-2 and HT-2 toxin contaminated feed on day 21 compared to control. Body weight was significantly lower as a result of feeding T-2 and HT-2 toxin contaminated diet. However, the contamination did not cause a significant increase of malondialdehyde content in the analysed tissues. Reduced glutathione content was significantly lower in the liver homogenate on day 39 than that of the control. Glutathione peroxidase activity also did not differ significantly in blood plasma, red blood cell haemolysates and kidney homogenates, while it was significantly higher in the liver homogenates of the mycotoxin-challenged birds.

In conclusion, it can be stated that T-2 and HT-2 toxin exposure has long-term effects in broiler chickens
\end{abstract}

\section{T-2 toxin, HT-2 toxin, malondialdehyde, glutathione, glutathione peroxidase, chicken}

Fusarium moulds are widespread in the temperate climate, producing trichothecene mycotoxins, e.g. T-2 toxin, HT-2 toxin, T-2 triol and T-2 tetraol (Scott 1990). Due to their occurrence and diverse effects, in particular impairment of the immune response (Weber et al. 2008), these mycotoxins have great importance in animal nutrition. The trichothecene mycotoxins, such as T-2 toxin and its metabolites compromise the growth rate and development of poultry (Leeson et al. 1995), and affect the antioxidant status (Atroshi et al. 2002; Rizzo et al. 1994; Weber et al. 2007), primarily due to their prooxidant effect (Mézes et al. 1998; Surai 2002). Among the Fusarium mycotoxins, the $\mathrm{T}-2$ toxin and its natural metabolites are excreted relatively quickly (within about $72 \mathrm{~h}$ ) from the organism after ingestion. Therefore, the rate of their accumulation in the different tissues is low (e.g. $0.2 \%$ in muscles and $0.4 \%$ in the liver). Thus the main detrimental effects of the T-2 toxin and its metabolites are not due to their accumulation, but rather the result of other, sometimes long-term effects caused immediately after absorption and metabolism of toxins in different tissues (WHO/FAO 2000).

The objective of the present study was to evaluate the long-term effect of feeding T-2 toxin contaminated diet on the growth, rate of lipid peroxidation, and also on the glutathione redox status of broiler chickens during the growing period.

Address for correspondence:

Miklós Mézes

Department of Nutrition, Szent István University

H-2103 Gödöllő, Páter Károly u. 1., Hungary
Phone: +3628410735

Fax: +3628410804

Email: Mezes.Miklos@mkk.szie.hu

http://www.vfu.cz/acta-vet/actavet.htm 


\section{Materials and Methods}

A total of 40 day-old Hubbard broiler cockerels were studied for 39 days. The birds were divided into two groups fed with control ('C' $\mathrm{n}=20$ ) and T-2 toxin contaminated ('T-2' $\mathrm{n}=20$ ) diets. The nutrient content of the diets met the requirements for broiler chickens (Table 1) according to the Hungarian standards (Hungarian Feed Code 2004a). The nutrient content of the diets was determined according to the Hungarian National Standard methods (Hungarian Feed Code 2004b). Complete feed in mash form was fed in the first phase (1-21 days) with $<0.01 \mathrm{mg} \cdot \mathrm{kg}^{-1} \mathrm{~T}-2$ toxin in the control, while the experimentally contaminated diets contained $1.04 \mathrm{mg} \cdot \mathrm{kg}^{-1} \mathrm{~T}-2$ toxin and $0.49 \mathrm{mg} \cdot \mathrm{kg}^{-1} \mathrm{HT}-2$ toxin, respectively. The same control complete feed with $<0.01 \mathrm{mg} \cdot \mathrm{kg}^{-1} \mathrm{~T}-2$ toxin was fed in the second phase (22-39 days) with the same nutrient content as in the first phase, while the experimentally contaminated diets were loaded with $0.12 \mathrm{mg} \cdot \mathrm{kg}^{-1} \mathrm{~T}-2$ toxin and $0.02 \mathrm{mg} \cdot \mathrm{kg}^{-1} \mathrm{HT}-2$ toxin, respectively.

Table 1. Nutrient and mycotoxin content of the diets

\begin{tabular}{|l|c|c|c|c|}
\hline Nutrient & Starter control & Finisher control & Starter 'T-2' & Finisher 'T-2' \\
\hline Dry matter g.kg-1 & 898.80 & 895.30 & 897.90 & 896.10 \\
\hline Crude protein $\mathrm{g} \cdot \mathrm{kg}^{-1}$ D.M. & 196.37 & 187.25 & 193.45 & 187.40 \\
\hline Crude fat $\mathrm{g} \cdot \mathrm{kg}^{-1}$ D.M. & 30.15 & 31.30 & 30.29 & 31.25 \\
\hline Crude fibre $\cdot \mathrm{kg}^{-1}$ D.M. & 23.59 & 24.10 & 25.39 & 24.40 \\
\hline Crude ash $\mathrm{g} \cdot \mathrm{kg}^{-1}$ D.M. & 62.97 & 63.15 & 63.70 & 63.40 \\
\hline Nitrogen free extract g.kg-1 D.M. & 686.92 & 694.20 & 687.16 & 693.55 \\
\hline T-2 toxin $\mathrm{mg} \cdot \mathrm{kg}^{-1}$ D.M. & $<0.01$ & $<0.01$ & 1.04 & 0.12 \\
\hline HT-2 toxin mg.kg-1 D.M. & $<0.01$ & $<0.01$ & 0.49 & 0.02 \\
\hline
\end{tabular}

D.M. $=$ dry matter

However, there is no official regulation in the European Union for the maximum allowed level of T-2 toxin in the feeds, only a guideline for the limit value of $0.5 \mathrm{mg} \mathrm{T}-2$ toxin $\cdot \mathrm{kg}^{-1}$ is proposed (Eriksen and Pettersson 2004). $\mathrm{T}-2$ toxin contamination in the first phase of the present experiment was much higher than the aforementioned maximum guideline limit value. The partially purified toxin preparation was dissolved in acetone and then sprayed onto the complete feed $(100 \mathrm{ml} / 50 \mathrm{~kg}$ of feed). T-2 toxin was produced experimentally on maize by Fusarium sporotrichoides strain NRRL 3229 (Agricultural Research Service Culture Collection, National Centre for Agricultural Utilization Research, Peoria, IL) according to the method of Fodor et al. (2006). Extraction and purification of the toxin were carried out according to Burmeister (1971). The T-2 and HT-2 toxin concentrations in the feed were measured using the HPLC technique (Central Veterinary Institute, Budapest) according to the relevant European Union directive (EU 2005). The amounts of related trichothecene metabolites, T-2 triol and T-2 tetraol were under the detection limit.

Body weight was measured on the $7^{\text {th }}, 14^{\text {th }}, 21^{\text {st }}, 35^{\text {th }}$ and $39^{\text {th }}$ days of the trial. Five animals from each group were sacrificed on $21^{\text {st }}$ and $39^{\text {th }}$ days, necropsy was carried out, and blood and tissue (liver and kidney) samples were collected. Blood samples were stored at cooled place $\left(+4{ }^{\circ} \mathrm{C}\right)$ until processing, then the plasma was separated from the blood cells by centrifugation. Red blood cells were lysed with deionized water (ratio $1: 9$ ) and by freezing and thawing. Liver and kidney samples were homogenized in nine-fold volume of $0.65 \%(\mathrm{w} / \mathrm{v})$ sodium-chloride. The samples were stored at $-20^{\circ} \mathrm{C}$ until analyses.

For determination of malondialdehyde (MDA) concentration in the blood samples, the method of Placer et al. (1966) and for liver and kidney samples the method of Mihara et al. (1980) were used. The glutathione peroxidase (GSHPx) activity was measured by the method of Lawrence and Burk (1976). Protein content of the blood plasma and the red blood cell haemolysate was determined by the biuret method (Weichselbaum 1948). Total protein concentrations in the 10,000 $\mathrm{g}$ supernatant fraction of liver and kidney homogenates were measured according to the method of Lowry et al. (1951). The GSH concentration was analysed using the method of Sedlak and Lindsay (1968).

Statistical evaluation of the results was carried out by paired Student's $t$-test after calculating the means and standard deviations (S.D.) with Statistica ${ }^{\mathrm{TM}} 4.0$ (Statsoft Inc. 1993) software. The experiment was approved by the Animal Experimental Committee of the Faculty of Agricultural and Environmental Sciences of the Szent István University $(2 / 2005)$.

\section{Results}

\section{Pathological signs}

The effects of T-2 and HT-2 toxin were found at necropsy on day 21 and also on day 39 but with different extents and rates of occurrence in the group fed mycotoxin contaminated feed. The pathological signs appeared as lesions in the oral cavity and on the tongue, also 
Table 2. Clinical signs of intoxication after long term feeding of T-2 and HT-2 toxin contaminated feed

\begin{tabular}{|l|c|c|c|c|}
\hline \multirow{2}{*}{ Group } & \multicolumn{2}{|c|}{$\begin{array}{c}\text { Lesions in oral cavity and } \\
\text { on tongue }\end{array}$} & \multicolumn{2}{|c|}{$\begin{array}{c}\text { Inflammation in the } \\
\text { intestine }\end{array}$} \\
\cline { 2 - 5 } & Day 39 & Day 21 & Day 39 & Day 21 \\
\hline Control & $0 / 10$ & $0 / 10$ & $0 / 10$ & $0 / 10$ \\
\hline T-2+HT-2 toxin treated & $6 / 10$ & $3 / 10$ & $4 / 10$ & $1 / 10$ \\
\hline
\end{tabular}

haemorrhage and inflammatory symptoms especially in the proximal part of the small intestine were found (Table 2).

Body weight

Body weight of the birds was significantly lower after feeding T-2 and HT-2 toxin contaminated feed at the end of the starter (high toxin concentration) period on day 21 (Table 3). During the second phase of the trial with a lower dose of mycotoxin contamination, compensatory growth occurred in the toxin-fed group.

Table 3. Body weight of broiler chickens after long term feeding of T-2 and HT-2 toxin-contaminated feed $($ mean $\pm \mathrm{SD})$

\begin{tabular}{|c|c|c|}
\hline \multirow{2}{*}{$\begin{array}{c}\text { Age } \\
\text { days }\end{array}$} & \multicolumn{2}{|c|}{ Body weight $(\mathrm{g})$} \\
\cline { 2 - 3 } & Control & \multicolumn{1}{|c|}{ T-2+HT-2 toxin } \\
\hline 0 & $41.6 \pm 1.0$ & $41.4 \pm 2.7$ \\
\hline 7 & $125.0 \pm 19.5$ & $121.1 \pm 13.0$ \\
\hline 14 & $319.8 \pm 48.2$ & $280.7 \pm 34.5$ \\
\hline 21 & $665.2^{\mathrm{a}} \pm 103.9$ & $574.1^{\mathrm{b}} \pm 80.1$ \\
\hline 28 & $1028.3 \pm 200.7$ & $936.7 \pm 199.5$ \\
\hline 35 & $1508.8 \pm 292.4$ & $1387.5 \pm 278.2$ \\
\hline 39 & $1795.4 \pm 341.3$ & $1630.4 \pm 310.6$ \\
\hline
\end{tabular}

${ }^{\mathrm{a}, \mathrm{b}}$ Different superscripts in the same row mean significant difference $(P<0.05)$

Table 4. Malondialdehyde content in blood plasma, red blood cell haemolysate, liver and kidney homogenates after long term feeding of $\mathrm{T}-2+\mathrm{HT}-2$ toxin-contaminated feed $($ mean $\pm \mathrm{SD})$

\begin{tabular}{|c|c|c|c|}
\hline Sample & $\begin{array}{l}\text { Age } \\
\text { days }\end{array}$ & Control & $\begin{array}{c}\mathrm{T}-2+\mathrm{HT}-2 \text { toxin } \\
\text { treated }\end{array}$ \\
\hline \multirow{2}{*}{$\begin{array}{l}\text { Blood plasma } \\
\left(\mu \mathrm{mol} \cdot 1^{-1}\right)\end{array}$} & 21 & $6.3 \pm 2.88$ & $2.62 \pm 0.34$ \\
\hline & 39 & $7.13 \pm 1.94$ & $6.90 \pm 1.65$ \\
\hline \multirow{2}{*}{$\begin{array}{l}\text { RBC haemolysate } \\
\left(\mu \mathrm{mol} \cdot 1^{-1}\right)\end{array}$} & 21 & $7.92 \pm 0.78^{\mathrm{a}}$ & $6.44 \pm 0.59^{b}$ \\
\hline & 39 & $8.52 \pm 2.80$ & $7.74 \pm 3.08$ \\
\hline \multirow{2}{*}{$\begin{array}{l}\text { Liver homogenate } \\
\left(\mu \mathrm{mol} \cdot \mathrm{g}^{-1} \text { wet weight }\right)\end{array}$} & 21 & $3.46 \pm 0.85$ & $3.02 \pm 0.55$ \\
\hline & 39 & $5.26 \pm 1.80$ & $5.02 \pm 1.15$ \\
\hline \multirow{2}{*}{$\begin{array}{l}\text { Kidney homogenate } \\
\left(\mu \mathrm{mol} \cdot \mathrm{g}^{-1} \text { wet weight }\right)\end{array}$} & 21 & $5.87 \pm 0.74$ & $7.27 \pm 2.19$ \\
\hline & 39 & $6.85 \pm 1.24^{\mathrm{a}}$ & $4.14 \pm 1.22^{b}$ \\
\hline
\end{tabular}

${ }^{\mathrm{a}, \mathrm{b}}$ Different superscripts in the same row mean significant difference $(P<0.05)$

\section{Malondialdehyde content}

Lipid peroxidation was followed by measuring the concentration of the malondialdehyde, a meta-stable end-product of peroxidation of non-saturated fatty acids. There were no significant changes in the malondialdehyde content of blood plasma and liver homogenate following the feeding of T-2 and HT-2 toxin-contaminated diet. However, significantly lower malondialdehyde content was found in the red blood cell haemolysates on day 21 and in kidney homogenates on day 39 of the birds from toxin group compared to control (Table 4).

\section{Glutathione peroxidase activity}

Glutathione peroxidase activity did not differ significantly in the blood plasma, red blood cell haemolysate and 10,000 $\mathrm{g}$ supernatant fraction of kidney homogenates as an effect of feeding T-2 and HT-2 toxin-contaminated diet (Table 6). On the contrary, the enzyme activity was significantly higher in the $10,000 \mathrm{~g}$ supernatant fraction of liver homogenates of the birds from the toxin group at both times of samplings, namely on days 21 and 39, compared to control (Table 6). 
Table 5. Reduced glutathione content in blood plasma, red blood cell haemolysate, and 10,000 $\mathrm{g}$ supernatant fraction of liver and kidney homogenates after long term feeding of T-2 + HT-2 toxin-contaminated feed $($ mean $\pm \mathrm{SD})$

\begin{tabular}{|l|c|c|c|}
\hline Sample & $\begin{array}{c}\text { Age } \\
\text { days }\end{array}$ & Control & $\begin{array}{c}\text { T-2 }+ \text { HT-2 toxin } \\
\text { treated }\end{array}$ \\
\hline $\begin{array}{l}\text { Blood plasma } \\
\left(\mu \mathrm{mol} \cdot \mathrm{l}^{-1}\right)\end{array}$ & 21 & $6.29 \pm 1.28$ & $5.18 \pm 2.07$ \\
\cline { 2 - 4 } $\begin{array}{l}\text { RBC haemolysate } \\
\left(\mu \mathrm{mol} \cdot \mathrm{I}^{-1}\right)\end{array}$ & 39 & $4.80 \pm 0.69$ & $5.25 \pm 0.83$ \\
\hline \multirow{2}{*}{$\begin{array}{l}\text { Liver homogenate } \\
\left(\mu \mathrm{mol} \cdot \mathrm{g}^{-1} \text { protein }\right)\end{array}$} & 39 & $10.33 \pm 1.82$ & $10.73 \pm 2.43$ \\
\hline $\begin{array}{l}\text { Kidney homogenate } \\
\left(\mu \mathrm{mol} \cdot \mathrm{g}^{-1} \text { protein }\right)\end{array}$ & 39 & $2.56 \pm 0.60$ & $3.00 \pm 0.66$ \\
\cline { 2 - 4 } & 39 & $1.82 \pm 2.59^{\mathrm{a}}$ & $0.61 \pm 0.77^{\mathrm{b}}$ \\
\hline
\end{tabular}

${ }^{a, b}$ Different superscripts in the same row mean significant difference $(P<0.05)$

Table 6. Glutathione peroxidase activity in blood plasma, red blood cell haemolysate, and 10,000 $\mathrm{g}$ supernatant fraction of liver and kidney homogenates after long-term feeding of T-2 + HT-2 toxin-contaminated feed (mean \pm SD)

\begin{tabular}{|c|c|c|c|}
\hline \multirow{2}{*}{ Sample } & \multirow{2}{*}{$\begin{array}{l}\text { Age } \\
\text { days }\end{array}$} & \multicolumn{2}{|c|}{ Glutathione peroxidase activity } \\
\hline & & Control & T-2 + HT-2 toxin \\
\hline \multirow{2}{*}{$\begin{array}{l}\text { Blood plasma } \\
\left(\mu \mathrm{kat} \cdot \cdot^{-1}\right)\end{array}$} & 21 & $8.67 \pm 1.51$ & $7.31 \pm 2.72$ \\
\hline & 39 & $6.99 \pm 1.64$ & $7.59 \pm 0.96$ \\
\hline \multirow{2}{*}{$\begin{array}{l}\text { RBC haemolysates } \\
\left(\mu \mathrm{kat} \cdot \mathrm{l}^{-1}\right)\end{array}$} & 21 & $4.84 \pm 1.62$ & $6.50 \pm 2.16$ \\
\hline & 39 & $5.51 \pm 1.26$ & $5.45 \pm 1.20$ \\
\hline \multirow{2}{*}{$\begin{array}{l}\text { Liver homogenate } \\
\text { (nkat } \cdot \mathrm{g}^{-1} 10000 \mathrm{~g} \\
\text { supernatant protein) }\end{array}$} & 21 & $47.26 \pm 8.68^{a}$ & $58.28 \pm 5.85^{\mathrm{b}}$ \\
\hline & 39 & $31.90 \pm 6.51^{\mathrm{a}}$ & $41.58 \pm 10.52^{b}$ \\
\hline \multirow{2}{*}{$\begin{array}{l}\text { Kidney homogenate } \\
\text { (nkat } \cdot \mathrm{g}^{-1} 10000 \mathrm{~g} \\
\text { supernatant protein) }\end{array}$} & 21 & $19.21 \pm 8.35$ & $25.22 \pm 7.68$ \\
\hline & $39 d$ & $24.88 \pm 8.02$ & $27.05 \pm 5.01$ \\
\hline
\end{tabular}

${ }^{\mathrm{a}, \mathrm{b}}$ Different superscripts in the same row mean significant difference $(P<0.05)$

\section{Discussion}

The clinical signs of T-2 and HT-2 toxicity were the same as previously described (Joffe et al. 1971; Gentry 1982). Severity of these alterations decreased but did not completely cease during the second phase of the trial when the mycotoxin content of the diet was much lower. It means that a high dose of T-2 and HT-2 toxinload has a long-term effect even if followed by a much lower level of contamination. The same effect was found for live weight, which was significantly lower in the T-2 group at the end of the starter period with a high level toxin contamination (1.04 mg. $\mathrm{kg}^{-1} \mathrm{~T}-2$ toxin and $0.49 \mathrm{mg} \cdot \mathrm{kg}^{-1}$ HT-2 toxin), but the difference between the two groups was negligible at the end of the trial. That was caused partly by the lower dose of mycotoxin contamination $\left(0.12 \mathrm{mg} \cdot \mathrm{kg}^{-1} \mathrm{~T}-2\right.$ toxin and $0.02 \mathrm{mg} \cdot \mathrm{kg}^{-1} \quad \mathrm{HT}-2$ toxin) during the second phase of the trial and also the well known compensatory growth ability of poultry species.

Changes of biochemical markers of lipid peroxidation and glutathione redox system are in line with the findings of Leal et al. (1999) and Weber et al. (2006). Significant difference was found at the end of the high dose T-2 and HT-2 toxin-challenge on day 21 but also at the end of the trial when the mycotoxin contamination of the diet was much lower. The higher glutathione peroxidase activity in the liver homogenate at both samplings suggests that T-2 and HT-2 toxin load, even at low level, activates the antioxidant defence system in a tissue-specific manner (Brigelius-Flohé 1999). Activation of glutathione peroxidase might be the result of post-translational activation of the enzyme due to the well known inhibitory effect of T-2 toxin on protein synthesis (Ueno et al. 1973).

These findings support our hypothesis that the effects of a high level T-2 and HT-2 toxincontaminated feed in broiler chickens persist for a longer period of time even when it is followed by a lower challenge.

\section{Acknowledgement}

The financial support received from the Hungarian Academy of Sciences (Animal Breeding and Animal Hygiene Academy Research Group) is gratefully acknowledged. 


\section{References}

Brigelius-Flohé R 1999: Tissue specific functions of individual glutathione peroxidases. Free Radic Biol Med 27: $951-965$

Burmeister HR 1971: T-2 production by Fusarium tricinctum on solid substrate. Appl Microbiol 21: 739-742

Eriksen GS, Pettersson H 2004: Toxicological evaluation of trichothecenes in animal feed. Anim Feed Sci Technol 114: $205-239$

EU 2005: Council Directive 2005/38/EC - laying down the sampling methods and the methods of analysis for the official control of the levels of Fusarium toxins in foodstuffs. Off J European Union L 143/52, p. 18-19

Fodor J, Németh M, Kametler L, Pósa R, Kovács M, Horn P 2006: Novel methods of Fusarium toxins' production for toxicological experiments. Acta Agraria Kaposváriensis. 10: 277-285

Gentry PA 1982: The effect of administration of a single dose of T-2 toxin on blood coagulation parameters in the rabbit. Can J Comp Med 46: 414-419

Hungarian Feed Code 2004a: Nutrient requirement of broiler chicken (In Hungarian), OMMI, Budapest, Vol. II., pp. $65-67$

Hungarian Feed Code 2004b: Methods for the determination of nutrients in feedinfstuffs and complete feeds (In Hungarian), OMMI, Budapest, Vol. III. pp. 101-533

Joffe BI, Novis B, Seftel HC, Krut L, Bank S 1971: Ischaemic heart-disease and pancreatic diabetes. Lancet 298: 269

Lawrence RA, Burk RF 1976: Glutathione peroxidase activity in selenium deficient rat liver. Biochem Biophys Res Commun 71: 952-956

Leeson S, Diaz G, Summers JD 1995: Poultry metabolic disorders and mycotoxins. University Books, Guelph; pp. 190-226

Lowry OH, Rosenbrough NJ, Farr AL, Randall RJ 1951: Protein measurement with the Folin phenol reagent. J Biol Chem 193: 265-275

Mézes M, Barta M, Nagy G 1998: Comparative investigation on the effect of T-2 mycotoxin on lipid peroxidation and antioxidant status in different poultry species. Res Vet Sci 66:19-23

Mihara M, Uchiyama M, Fukuzawa K 1980: Thiobarbituric acid value of fresh homogenate of rat as parameter of lipid peroxidation in ageing, CCl4 intoxication and vitamin E deficiency. Biochem Med 23: 302-311

Placer ZA, Cushman LL, Johnson BC 1966: Estimation of product of lipid peroxidation (malonyldialdehyde) in biochemical systems. Anal Biochem 16: 359-364

Rizzo AF, Atroshi F, Ahotupa M, Sankari S, Elovaara E 1994: Protective effect of antioxidants against free radical-mediated lipid peroxidation induced by DON or T-2 toxin. Nat Toxins 1: 106-110

Scott PM 1990: Trichothecenes in grains. Cer Foods World 35: 661-666

Sedlak I, Lindsay RH 1968: Estimation of total, protein-bound and non-protein sulfhydryl groups in tissues with Ellmann's reagent. Anal Biochem 25: 192-205

Sies H 1999: Glutathione and its role in cellular functions. Free Radic Biol Med 27: 916-921

Surai PF 2002: Natural antioxidants in avian nutrition and reproduction. Nottingham University Press, Nottingham, pp. $455-510$

Ueno Y, Nakajima M, Sakai K, Ishii K, Sato N, Shimada N 1973: Comparative toxicity of trichothecene mycotoxins: Inhibition of protein synthesis in animal cells. J Biochem 74: 285-292

Weber M, Fodor J, Stiller Sz, Balogh K, Wágner L, Erdélyi M, Mézes M 2006: Lipid peroxide and antioxidant status of broiler chickens after oral administration of Fusarium sporotrichoides fungal culture. Cereal Res Comm 34: 763-766

Weber M, Stiller Sz, Balogh K, Wágner L, Erdélyi M, Mézes M 2007: Effect of feeding T-2 toxin contaminated feed on the utilization of vitamin E in chickens. Acta Vet Hung 55: 21-27

Weber M, Fodor J, Balogh K, Wágner L, Erdélyi M, Mézes M 2008: Effect of vitamin E supplementation on immunity against Newcastle diseases virus in T-2 toxin challenged chickens. Acta Vet Brno 77: 45-49

Weichselbaum TE 1948: An accurate and rapid method for the determination of protein in small amounts of serum and plasma. Am J Clin Pathol 16: 40-43

WHO/FAO 2000: Safety evaluation of certain mycotoxins in food. WHO Food Additive Series: 47, FAO Food and Nutrition Paper No. 74, WHO, Geneva pp. 680 
